\title{
GEOTHERMAL POTENTIAL AND SUSTAINABLE USE OF KARST GROUNDWATER IN URBAN AREAS-BELGRADE, CAPITAL OF SERBIA CASE STUDY
}

\author{
GEOTERMALNI POTENCIAL IN TRAJNOSTNA RABA KRAŠKE \\ PODTALNICE NA URBANIH OBMOČJIH - PRIMER BEOGRADA, \\ GLAVNEGA MESTA SRBIJE
}

\author{
Dejan MILENIC ${ }^{1}$ \& Ana VRANJES ${ }^{1}$
}

\begin{abstract}
UDC 662.997:551.444(497.11Beograd)

Dejan Milenic \& Ana Vranjes: Geothermal potential and sustainable use of karst groundwater in urban areas-Belgrade, capital of Serbia case study

The increase in energy demand due to urban expansion and migration to urban areas has a negative impact on the environment and the city budget. Development plans of cities are more frequently based on the implementation of energy efficiency measures, which among other things include the use of renewable energy sources. In the area of Belgrade, research was conducted aimed at assessing the geothermal potentiality of the field and defining the possibility of groundwater exploitation. The research has been directed to groundwater formed in karst aquifers. Geothermal field evaluation was preceded by the formation of geological and hydrogeological bases, then, the development of a conceptual model of karst distribution in the city area and the systematization of data measured in the observation well network. The potentiality assessment is followed by defining of the conditions and possibilities of the exploitation of karst water as a form of geothermal energy in heat pump systems. In the exploitation of karst water in the city, it is significant to establish mechanisms of sustainable management, especially in terms of protection of resources. In recent years, there has been recorded a constant increase in the number of heating and cooling systems of buildings using groundwater as an energy source in the territory of Belgrade. Potential causes of the negative impact of exploitation of karst water are the overexploitation of resources, creating of the effect of "thermal feedback" as a result of incompetent disposition, namely restoring of groundwater to the aquifer.
\end{abstract}

Keywords: geothermal energy, karst aquifer, urban area, sustainable utilisation.

\begin{abstract}
Izvleček UDK 662.997:551.444(497.11Beograd) Dejan Milenic \& Ana Vranjes: Geotermalni potencial in trajnostna raba kraške podtalnice na urbanih območjih - primer Beograda, glavnega mesta Srbije
\end{abstract}

Večanje potreb po energiji zaradi širitev urbanih okolij in migracij $\mathrm{v}$ mesta ima negativen vpliv na okolje in mestne proračune. Razvojni načrti mest bolj pogosto temeljijo na uvajanju ukrepov za varčevanje $\mathrm{z}$ energijo, ki med drugim vključujejo tudi rabo obnovljivih virov energije. Na območju mesta Beograda je bila izvedena raziskava $\mathrm{z}$ namenom izdelave ocene geotermalnega potenciala območja in možnosti izrabe podzemne vode. Usmerjena je bila $\mathrm{v}$ proučevanje podzemne kraške vode. Pred izdelavo ocene geotermalnega polja so bile narejene geološke in hidrogeološke podlage, nato postavljen konceptualni model razporeditve krasa $\mathrm{v}$ mestu in urejena baza podatkov merjenih v mreži opazovalnih vodnjakov. Oceni potenciala je sledila določitev pogojev in možnosti izrabe kraške vode kot oblike geotermalne energije $\mathrm{v}$ sistemu toplotnih črpalk. Pri izrabi kraške vode $v$ mestu je pomembno vzpostaviti mehanizme trajnostnega upravljanja, še posebej v smislu varovanja virov. V zadnjih letih je bilo na območju mesta Beograda zabeleženo stalno naraščanje števila sistemov ogrevanja in hlajenja stavb $\mathrm{z}$ uporabo podzemne vode kot vira energije. Možna vzroka negativnih vplivov izrabe kraške vode sta prekomerno izkoriščanje virov in ustvarjanje „povratnega toplotnega učinka“ zaradi neprimernega načina vračanja podzemne vode v vodonosnik.

Ključne besede: geotermalna energija, kraški vodonosnik, urbano območje, trajnostna raba.

\footnotetext{
${ }^{1}$ University of Belgrade, Faculty of Mining and Geology, Department of Hydrogeology, Djusina 7, 11000 Belgrade, Serbia, e-mail: dejan.milenic@rgf.bg.ac.rs,vranjes_ana@yahoo.ie
}

Received/Prejeto: 25.02.2014 


\section{SCOPE OF THE WORK AND SIGNIFICANCE OF RESEARCHING OF KARST AQUIFERS IN URBAN AREAS}

The expansion of urban surfaces and population growth in already existing urban areas is a distinctive phenomenon of the society management in the $21^{\text {st }}$ century. According to statistical estimates, more than a half of the world's population lives in cities, while in some countries even $90 \%$ of the population lives in urban areas (Marsalek et al. 2007). Intensive urbanization and disappearance of "free" green space on the account of asphalt and concrete, results in changing of conditions and the quality of the environment on one side, and on the other, in an increase in energy demand, since buildings are one of the largest consumers of energy. To meet energy needs (heating, air conditioning, interior lighting) buildings "consume" about $40 \%$ of the world energy , $16 \%$ of fresh water and $25 \%$ of timber, whereby $70 \%$ of the total emission of sulphur dioxide and $50 \%$ of total carbon dioxide emission is produced (Santamouris 2007).

According to the condition of the housing stock and the annual energy consumption for residential heating, Belgrade falls into the category of energy-inefficient cities. The largest number of flats (70\% of the existing housing stock) in the territory of Belgrade was built in the period before the year 1980, i.e. before the year 1987, when the first actual regulations on thermal protection of buildings were introduced. The annual energy consump- tion for heating of flats ranges from 150 to $250 \mathrm{kWh} / \mathrm{m}^{2}$, depending on the age and condition of the property $(\mathrm{Cu}-$ kovic Ignjatovic 2009).

Urban areas represent a unique system, which operates completely by the activity of anthropogenic factors, having a direct impact on the environment, inevitably, causing changes that are manifested in the form of micro-climatic changes. The impact of urbanization on groundwater resources, as one of environmental elements, is reflected in the change of groundwater recharge and exploitation conditions. The impact is indirect and affects water balance elements (precipitation, evaporation, run off).

On the other hand, in urban areas, groundwater suffers from multiple exposure to the risk of contamination, which is manifested in the form of chemical contamination or as "thermal feedback" pollution (the change of groundwater temperature in the aquifer under the impact of anthropogenic factors, which occurs due to uncontrolled "artificial" aquifer recharge).

The aforementioned urbanization impact on groundwater increases if the groundwater beneath the city is formed in karst aquifers. Open karst structures are directly exposed to anthropogenic impacts, thus accidents such as damages to the sewage system, the hot water

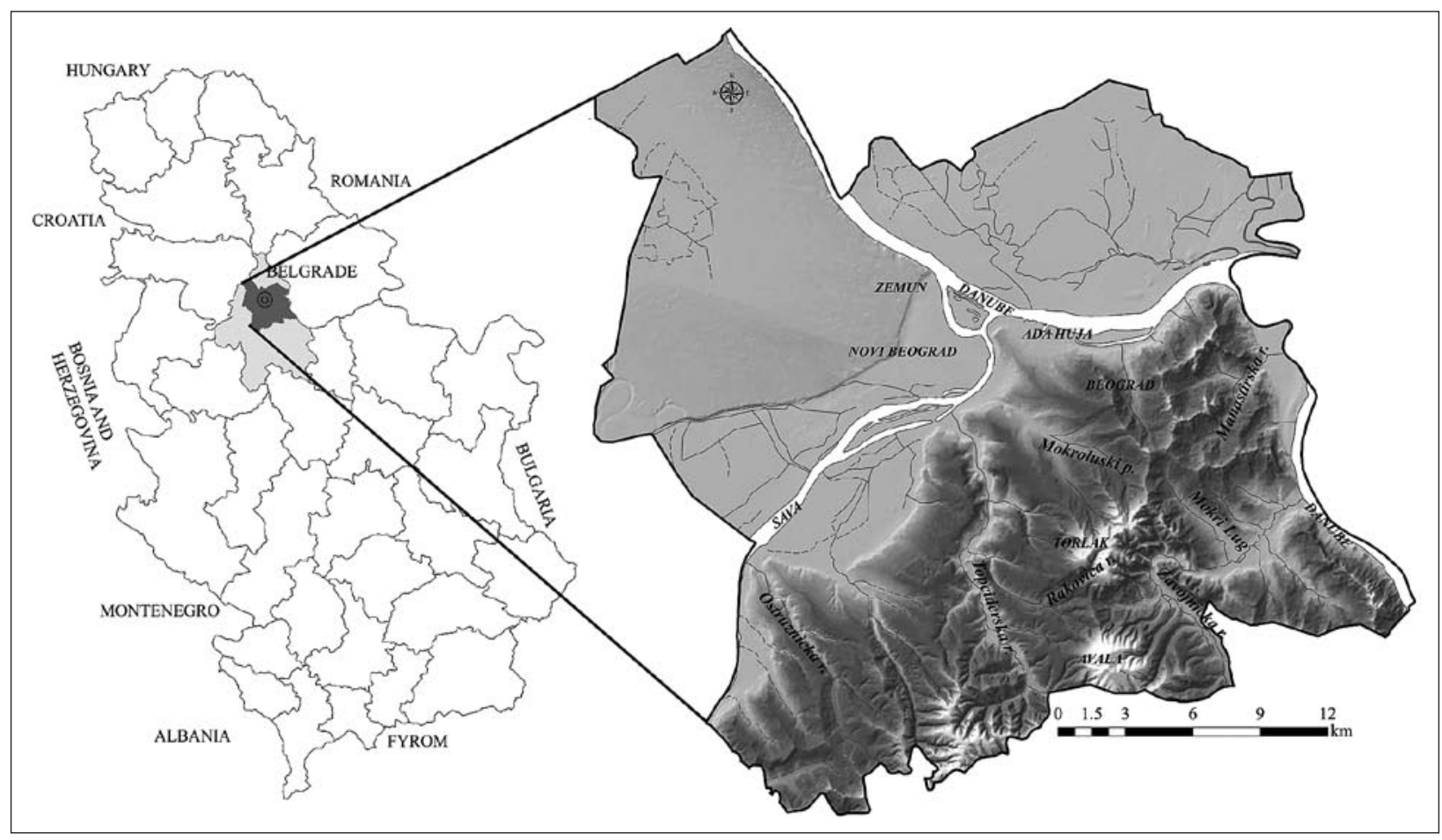

Fig. 1: Geographical position of Belgrade urban city area. 
network, the rain collector, the road and other asphalt surface drainage waters, a number of industrial plants, uncontrolled development of wells and groundwater return into the aquifer and inadequate storage of hazardous materials (petroleum and petroleum products, paints, varnishes ...) may adversely affect the karst water.

The significance of the research of karst aquifers in urban areas, in addition to the aspect of protection in recent years, is aimed at the exploitation of karst water as the geothermal resource for heating and cooling of buildings. Nowadays, due to the increasing energy needs strategic plans of town development are based on the use of renewable energy sources, and the evaluation of the geothermal potentiality of the terrain becomes part of planning documents in the development of detailed urban plans.

The city core of Belgrade is largely formed in karst parts of the terrain. For the purpose of assessing the geothermal potentiality of karst groundwater, defining the impact of urbanization on the karst aquifer, along with considering the conditions, opportunities and effect of karst water exploitation in the city of Belgrade area, there were analyzed:

General characteristics

- Climate characteristics with an urbanization impact analysis

- Hydrographic features with an urbanization impact analysis
- Geomorphologic features with an urbanization impact analysis

- Geological setting of the terrain

- Demographics with an analysis of urban population trends

- State in building with an analysis of the housing stock energy efficiency

- Thermal energy supply with an analysis of the existing capacity of remote heating

Geothermal characteristics

- Hydrogeological characteristics

- Karst distribution in the city of Belgrade area

- Karst aquifer features (conditions of recharge and discharge)

- Quantitative and qualitative characteristics of karst water

- Geothermal indicators in the city area

Results of the conducted research are presented for the urban city area (Fig. 1). The urban city area covers a surface of about $770 \mathrm{~km}^{2}$. In the entire territory of the city, there are approximately 1.650,000 inhabitants, of whom about $80 \%$ lives in the urban city area. Statistical data imply the growing tendency of urban population, namely $52 \%$ of the population moved to the territory of the city.

\section{GENERAL CHARACTERISTICS OF BELGRADE TERRITORY}

\section{CLIMATE CHARACTERISTICS OF BELGRADE URBAN CITY AREA}

The climate of Belgrade urban city area is considerably different from that of the surrounding area, which is primarily conditioned by the anthropogenic impact (urbanization of large areas), as well as by the impact of two factors, the radiation balance and water balance, which can be said to be characterized by local specificities (Unkasevic 1994). Different radiation balance is the consequence of the weaker reflection of solar radiation due to the existence of "street canyons". Differences in water balance are owing to minor sinking of precipita- tion in the soil as the soil is covered, whereby the runoff is increased and soil moisture reduced. The difference also arises in evaporation due to reduced soil moisture. The consequence of these differences results in stronger heating of the city area. Differences are also highly expressed in some other elements such as wind, fog and smog. The impacts of topography (vertical gradient), the base (rivers, land, vegetation) the city structure (urban "heat island") lay down local climatic specificities of Belgrade. Values of basic climatic elements in the territory of Belgrade are presented in Tab.1.

Tab. 1: Mean annual values of climatic elements in Belgrade urban city area.

\begin{tabular}{c|c|c|c|c|c}
\hline $\begin{array}{c}\text { Climatic } \\
\text { parameter }\end{array}$ & Precipitation & Temperature & Relative air humidity & $\begin{array}{c}\text { Atmospheric } \\
\text { pressure }\end{array}$ & $\begin{array}{c}\text { Potential } \\
\text { evapotranspiration }\end{array}$ \\
\hline Unit & $\mathrm{mm} / \mathrm{yr}$ & ${ }^{\circ} \mathrm{C}$ & $\%$ & $\mathrm{mbar}(\mathrm{hPa})$ & $\mathrm{mm} / \mathrm{yr}$ \\
\hline Value & 680 & 12 & 69 & 1001 & 649 \\
\hline
\end{tabular}




\section{HYDROGRAPHIC CHARACTERISTICS OF BELGRADE URBAN CITY AREA}

The hydrographic network of Belgrade area via the Sava and Danube catchment area belongs to the Black Sea basin. The average flow of the Danube in Belgrade is $5260 \mathrm{~m}^{3} / \mathrm{s}$, and of the Sava $1650 \mathrm{~m}^{3} / \mathrm{s}$. Lowland parts of the terrain north of the Sava and Danube rivers are characterized by a developed network of reclamation canals, with a total length of about $1000 \mathrm{~m}$, while natural streams are poorly developed. South of the Sava and Danube rivers, parts of "Belgrade hills" are characterized by a number of permanent and temporary streams. In this part of the field, there is a centrifugal type of the drainage network. Right tributaries of the Sava are the Ostruznicka Reka River, the Topciderska Reka River and the Mokroluski Potok stream, which is mostly piped. In the urban city core, the hydrographic network is altered under the influence of urbanization; rivers and streams are cased and carried into the sewage system. The left tributary of the Danube is the Tisa River, while the larger tributaries on the right bank are the Manastirska Reka River and the Zavojnicka Reka River (Fig. 1).

\section{GEOMOPHOLOGICAL CHARACTERISTICS OF BELGRADE URBAN CITY AREA}

Belgrade surroundings comprise two different natural units: the Pannonian plain in the north, and Sumadia, south of the Sava and Danube rivers (Fig. 1). The most prominent shape of the Sumadia hill relief, regarding the urban city area, is Avala hill $(511 \mathrm{~m})$, while Ada Huja Eyot with $70.15 \mathrm{~m}$ is the lowest elevation. The largest part of the Belgrade city core is located on a hilly, gently rolling relief. Eolian, karst and marine processes, among geomorphological processes, played a significant role, in shaping of the hilly terrain relief parts. The most interesting forms of the karst process are the Tasmajdan cave and the Tasmajdan cliff in the city center.

Parts of the terrain north of the Sava and Danube rivers are characterized by a typical lowland type of a terrain. Absolute elevations of this part of the field range from about $69 \mathrm{~m}$ to about $76 \mathrm{~m}$. In this part of the field, there are numerous ponds and marshes whose existence was caused by fluctuations in the level of the Danube River. The fluvial process played the most significant role in shaping of the lowland part of the field while shapes of proluvial and eolian processes (loess plateaus) are also visible.

\section{GEOLOGICAL AND HYDROGEOLOGICAL CHARACTERISTICS OF BELGRADE URBAN CITY AREA}

The oldest rocks in the city belong to the Paleozoic, and are found in farthest southwest of the territory. Begin- ning with the Paleozoic, rocks of Mesozoic and Cenozoic ages alternate, where hiatus can be perceived in sedimentation. Rocks of Jurassic age are the oldest member of the Mesozoic era in the urban city area. During the Upper Jurassic the differentiation of the seabed was made and a deep depression formed, which led to the creation of ophiolite, a diabase-chert formation, flysch, reef limestone. The complete development of the Cretaceous period may be traced in the city area. Flysch sediments both of Lower Cretaceous, and Upper Cretaceous ages are the most common members of the Belgrade area.

From the hydrogeological point of view, a significant member of the Cretaceous is a facies of reef and sub-reef limestones of Urgonian development. The Urgonian limestone facies is considerably distributed in the city center and its wider surroundings. Cretaceous sediments being in the Urgonian limestone facies are the floor to Tertiary sediments in the urban territory of Belgrade. The roof of Urgonian limestone is represented by limestones of Tortonian and Sarmatian age and Quaternary sediments. The thickness of the Urgonian limestone is unknown, since drill holes and wells did not enter the bed of Urgonian sediments.

During the Tertiary a limestone facies of Tortonian and Sarmatian ages was formed, which from the hydrogeological aspect also played a significant role in the formation of groundwater. The limestone facies of Tortonian age at the surface of the terrain was stated in central parts of the city, while in the wider city environment, a facies was discovered by drilling, thus its distribution is not clearly defined. Tortonian limestones in the central parts of the city lie in the Cretaceous bed, while being covered by a younger layer, most frequently by Pannonian clay and marl and loess deposits, and in some parts of the city Sarmatian sediments as well. The rugged reef paleorelief is the consequence of the absence of the Sarmatian over the Tortonian.

Sarmatian sediments have extensive distribution in the territory of the city of Belgrade being identified over the entire space. The Sarmatian sediments are represented by marl and marly limestone and limestone. It has been found, by test drilling, that the total thickness of the Sarmatian deposits is about $35 \mathrm{~m}$ (Knezevic \& Sumar 1994). The Sarmatian limestones gradually wedge out towards the confluence of the Sava into the Danube, as their thickness increases towards the central parts of the city. The development of Sarmatian limestone was found on the left bank of the Sava by drilling below gravel-sand layers at different depths from $20 \mathrm{~m}$ to $40 \mathrm{~m}$. Limestone of Sarmatian age was also found on the right bank of the Sava by test drilling.

In addition to limestone sediments of the Tortonian and Sarmatian, sandy-gravelly Quaternary sediments 


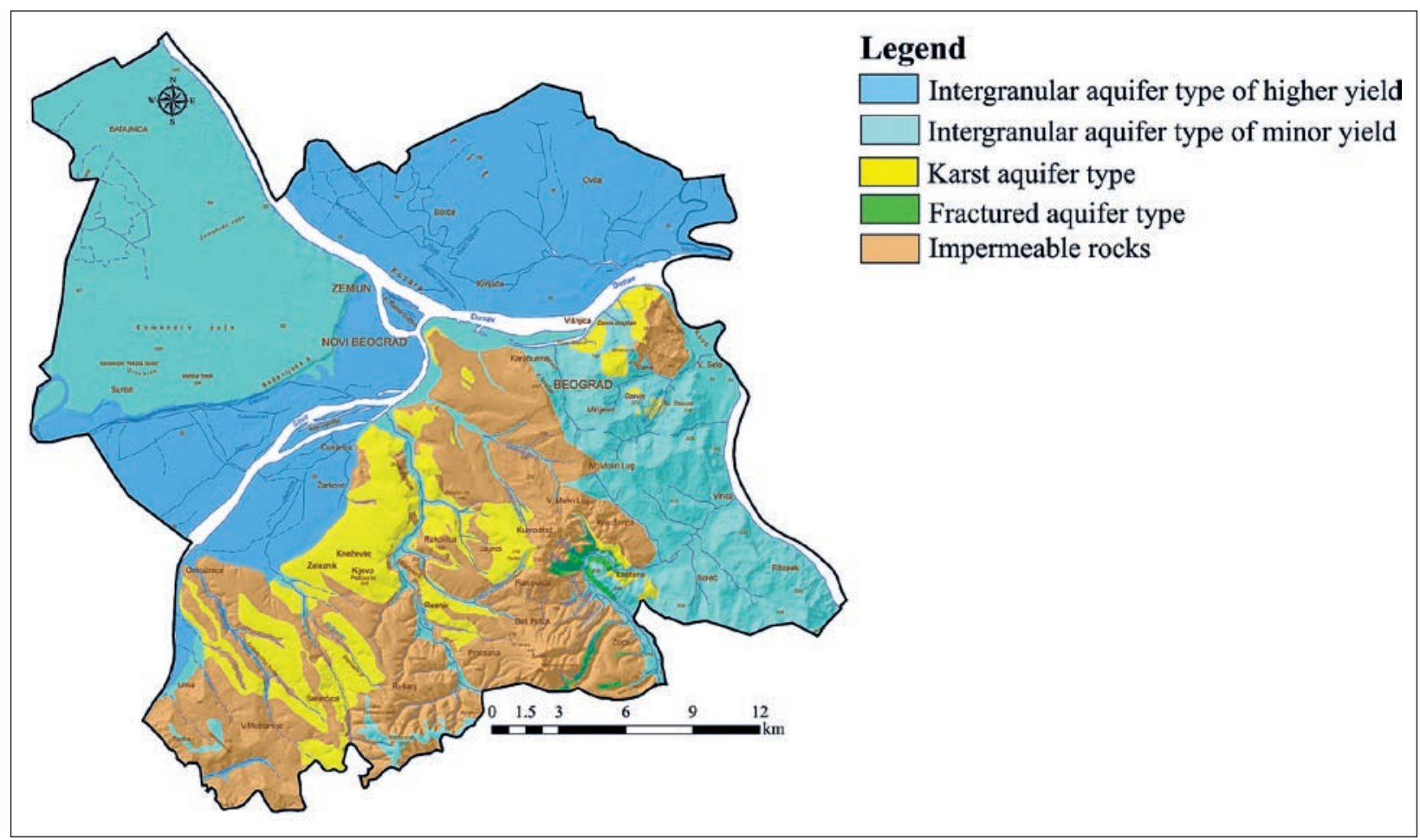

Fig. 2: Hydrogeological map of Belgrade urban city area.

play an important role in the formation of ground water resources. During the Quaternary at least twenty climate cycles have been recorded. During colder periods of the Quaternary Belgrade belonged to a periglacial area where loess deposits were accumulated. All parts of the Quaternary period, as well as all genetic types (except glacial) are represented in the vicinity of Belgrade.

Based on the structural type of porosity, in the urban city area, there were singled out:

- intergranular aquifer type of higher yield within sandy-gravel sediments
- intergranular aquifer type of minor yield within a sand facies of Sarmatian age

- karst aquifer within limestone of Cretaceous and Tortonian-Sarmatian age

- fractured aquifer within the serpentinite of Jurassic age

- impermeable parts of the terrain within the flysch sediments and clayey-sandy sediments of the Pannonian

A hydrogeological map of Belgrade urban city area is shown in Fig. 2.

\section{GEOTHERMAL CHARACTERISTICS AND NEW HYDROGEOLOGICAL ZONING OF BELGRADE}

Each hydrogeological phenomenon or facility with the groundwater temperature higher than the mean annual air temperature, whose value for Belgrade is $12^{\circ} \mathrm{C}$, points to a potential source of geothermal (hydrogeothermal) energy. The increased temperatures of groundwater in relation to the reference air temperature are the result of geological-tectonic structure and the hydrogeological conditions in the field, as well as anthropogenic activities.

\section{NEW HYDROGEOLOGICAL ZONING OF BELGRADE}

The new hydrogeological zoning largely relies on the existing one, and is based on the analysis of the data of hydrogeological explorations carried out in the last thirty years. The results of recent studies have confirmed the existing hydrogeological knowledge, but also pointed to the potential of so far unexplored parts of the terrain from the aspect of the tapping and exploitation of groundwater resources. The latest research, has primarily contributed 
Tab. 2: Yield and temperatures of groundwater measured in wells / piezometers within karst aquifer in city area.

\begin{tabular}{|c|c|c|c|}
\hline $\begin{array}{c}\text { Well/Piezometer } \\
\text { mark }\end{array}$ & $\begin{array}{c}\text { Well/Piezometer } \\
\text { depth }(m)\end{array}$ & $\begin{array}{l}\text { Well/Piezometer } \\
\text { yield }(I / s)\end{array}$ & $\begin{array}{c}\text { Groundwater } \\
\text { temperature }\left({ }^{\circ} \mathrm{C}\right)\end{array}$ \\
\hline \multicolumn{4}{|c|}{ Well depth up to do $100 \mathrm{~m}$} \\
\hline$B-1$ & 54.0 & I & 17 \\
\hline BS-1 & 61.0 & 9.0 & 22 \\
\hline PdUS-5 & 79.0 & 1 & 15.0 \\
\hline PdUS-1 & 80.0 & 1 & 15.0 \\
\hline CGL-1 & 80.0 & 1.0 & 17 \\
\hline PdUS-4 & 82.0 & I & 16.0 \\
\hline B-1 & 83.0 & 2.0 & 16 \\
\hline B-4 BIP & 87.00 & 9.0 & \\
\hline B-2 BIP & 94.00 & 12.0 & 16 \\
\hline IBS-1/11 & 97.0 & 2.0 & 17 \\
\hline \multicolumn{4}{|c|}{ Well depth $100-300 \mathrm{~m}$} \\
\hline B-1 BIP & 100.0 & 14.0 & 16.5 \\
\hline BBB-1 & 100.0 & 10.0 & 15 \\
\hline B-1/2000 & 100.0 & 10.0 & 16 \\
\hline IEBS-1/12 & 100.0 & 6.0 & 16 \\
\hline IB-1 & 100.0 & 5.0 & 16 \\
\hline IBS-1/11 & 100.0 & 2.0 & 15 \\
\hline $\mathrm{BM}-1$ & 101.0 & 2.0 & 17 \\
\hline BS-2 & 103.0 & 4.50 & 21 \\
\hline OB-1 & 162.0 & 2.0 & 21 \\
\hline IB-2 & 150.0 & 10.0 & 17 \\
\hline IEBV-1/08 & 106.0 & 3.0 & 21 \\
\hline IB-1 & 120.0 & 7.0 & 17 \\
\hline PdUS-3 & 130.0 & I & 15.0 \\
\hline IEBBD-1 & 141.0 & 4.0 & 20 \\
\hline $\mathrm{IB}-1$ & 142.0 & 2.0 & 16 \\
\hline B-3 BIP & 144.50 & 4.0 & 15.5 \\
\hline IB-1 & 152.0 & 1.0 & 17 \\
\hline \multicolumn{4}{|c|}{ Well depth 300-500 m } \\
\hline BS-3 & 321 & 15.0 & \\
\hline \multicolumn{4}{|c|}{ Well depth over $500 \mathrm{~m}$} \\
\hline $\mathrm{VL}-1$ & 800 & 0.3 flowing of well & 25 \\
\hline
\end{tabular}

to the perception of hydrogeological structure of deeper parts of the terrain and consideration of geometry of some types of aquifers. Newer geological explorations, carried out in the central parts of the city and in the vicinity of the mouth of the Sava river into the Danube, helped a great deal. In addition to the latest results of hydrogeological and geological explorations, the new zoning is carried out due to the territorial development of the city of Belgrade.

Hydrogeological zoning is made for the whole city of Belgrade territory, and there are singled out altogether ten areas with the corresponding sub-areas. The geological structure factor played the main role in singling out certain areas, then the hydrogeological structure factor while some areas were singled out according to the geomorphologic conditions in the field. The hydrogeological areas are singled out primarily for more complete and more systematic consideration of the hydrogeological characteristics of the study area, which is distinguished by its pronounced complexity. By creating the hydrogeological zoning, there were formed bases for the evaluation of geothermal potentiality of the terrain.

\section{GEOTHERMAL CHARACTERISTICS OF THE CITY OF BELGRADE TERRITORY}

The average values of heat flow for the city of Belgrade territory range from about $100 \mathrm{~mW} / \mathrm{m}^{2}$ to $120 \mathrm{~mW} / \mathrm{m}^{2}$, while the average value for the continental part of Europe is about $60 \mathrm{~mW} / \mathrm{m}^{2}$ (according to Cemark \& Rybach 1979 as cited by Milivojevic 1989). Values of the geother- 


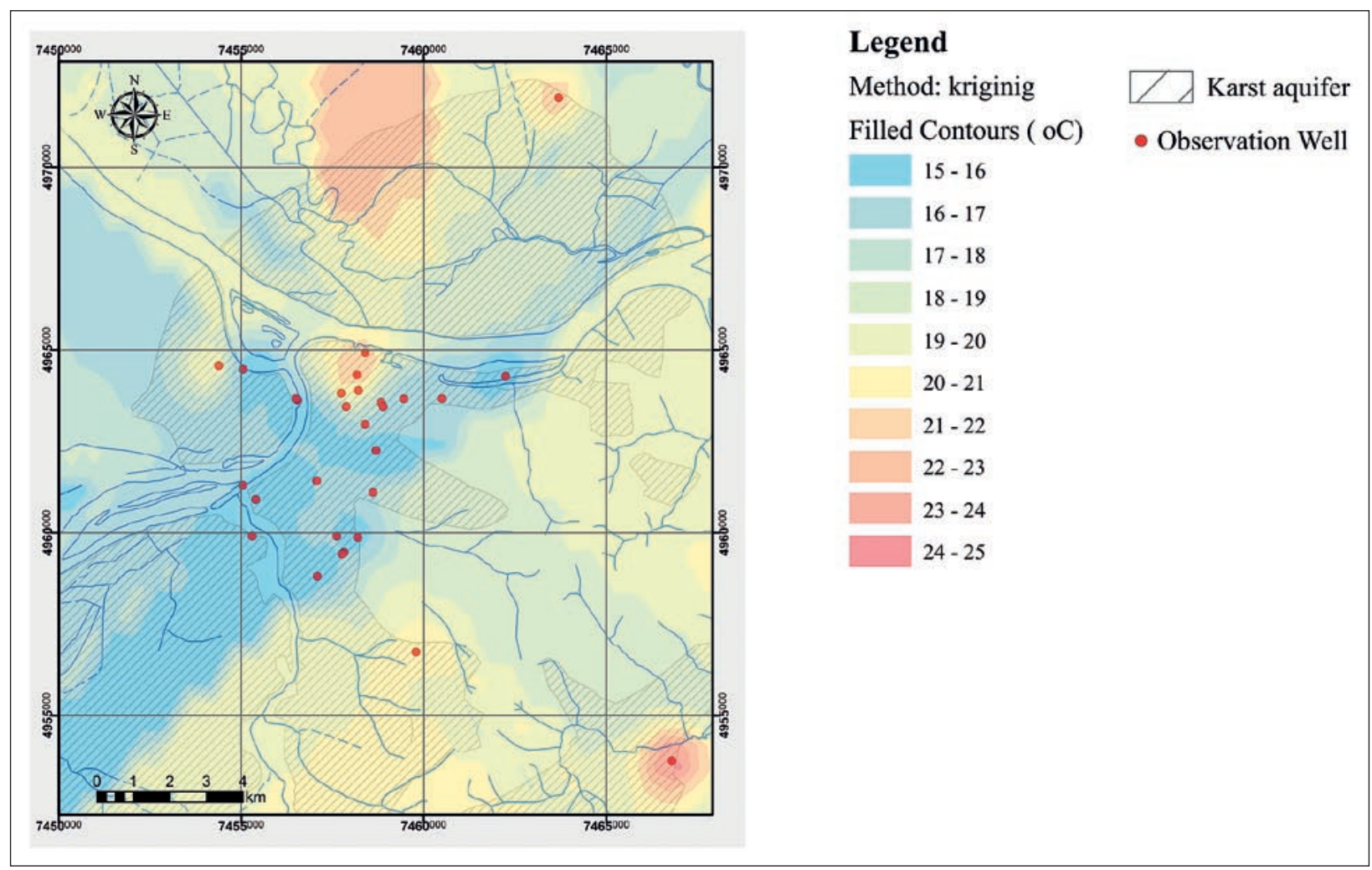

Fig. 3: Isotherms in urban city area.

mal degree throughout the city of Belgrade territory are higher in relation to the average increase in temperature in the continental parts of the Earth. The value of the geothermal degree in the central parts of the city is $10 \mathrm{~m} /{ }^{\circ} \mathrm{C}$ (Milivojevic 1982), while the largest anomalies were registered in the area of Avala hill (south-eastern parts farthest of the urban city area). East of Avala, in the valley of the Zavojnicka River, groundwater is formed within the karst aquifer, in a closed hydrogeological structure. The groundwater temperature measured at wells in the Zavojnicka River ranged from $19^{\circ} \mathrm{C}$ to $25^{\circ} \mathrm{C}$ (Fig. 5b). The increased temperatures are explained by the absence of circulation till the test holes are made within the karst aquifer. (Milivojevic 1982).

It is observed by analyzing hydrogeological phenomena and facilities in the territory of Belgrade through the survey of hydrogeological zones, that the groundwater temperature ranges from $11^{\circ} \mathrm{C}$ to $30^{\circ} \mathrm{C}$. Ground- water temperatures monitored at the spring range from $10{ }^{\circ} \mathrm{C}$ to $15^{\circ} \mathrm{C}$. The warmest occurrence of the groundwater is related to the karst aquifer in the central parts of the city core. While drilling, temperature on well BS-1 $(100 \mathrm{~m})$ in Skadarlija was $34^{\circ} \mathrm{C}$ (Dokmanovic 1997). During the exploitation of the aquifer the temperature dropped to $22-24^{\circ} \mathrm{C}$ (the BS-1 well location is shown in Fig. $5 \mathrm{~b}$ ). Within the urban city area, the highest drilling depth is $800 \mathrm{~m}$ (the well VL-1). The measured temperature of rocks at the well ort is $43^{\circ} \mathrm{C}$, and the groundwater temperature on the surface of the terrain is $25^{\circ} \mathrm{C}$. The hole is drilled in Sarmatian limestone (the location of the well is shown in Fig. 5b).

In Fig. 3 there are shown isotherms of the urban city core area designed on the basis of the groundwater temperatures measured at the wells and piezometers (Tab. 2).

\section{KARST AQUIFER OF BELGRADE, DISTRIBUTION AND BASIC CHARACTERISTICS}

The karst aquifer in the territory of Belgrade is formed within the limestone of Urgonian age as well as within the limestone of Tortonian and Sarmatian ages. Open karst surfaces occupy about $10 \%$ of the territory of the 
urban city area, being mainly the Tortonian-Sarmatian limestones. Although there are some differences in mechanical properties of rocks of Tortonian and Sarmatian ages (Tortonian limestone is sturdy, cracked to a lesser extent than the limestone of Sarmatian age and in colour they resemble the Urgonian limestone, while the Sarmatian limestone is cavernous, of white-yellow colour) the karst aquifer is observed as a part of the "package" of Tortonian and Sarmatian limestones, i.e. the stratigraphic division has not been conducted. In order to assess the geothermal potentiality of the terrain and to define the conditions and possibilities of exploitation of the karst groundwater, a conceptual model of the assumed limestone distribution in the urban city area has been developed, and the conditions of the karst aquifer recharge and drainage as well as the basic chemical properties of the karst waters perceived. The model of the limestone distribution is made on the basis of karst surface development and on the basis of data obtained by the exploratory drilling.

\section{DISTRIBUTION OF KARST AQUIFER}

Limestone of Cretaceous age $\left(K_{1}^{4-5}\right)$. In the urban territory of Belgrade, limestone of Cretaceous age is found on the left and right sides of the Topcider River (Fig. 5a).The limestone extends discontinuously, which is probably the consequence of sedimentation, namely the appearances of paleorelief. Drilling in parts of the city center over the Urgon limestone of Tortonian and Sarmatian ages was found. The thickness of the limestone of Urgon age is not known, since drill holes and wells did not enter the bed of Urgon sediments.

Limestone of Tortonian-Sarmatian age $\left(M_{2}^{2}-M_{3}^{1}\right)$. The development of Tortonian limestone can be traced along the Sava slope (right bank), from flowing of the Mokri Lug Stream into the Sava to the Kalemegdan area. Limestone is also noted in the left side of the Sava, along the left bank of the confluence. Tortonian limestone lies in the Cretaceous bed in the central part of the city. It emerges partly to the surface, affecting the steep relief of the urban areas, and, partly, it is overlain by younger layers (Sarmatian limestone). Moving away from the city center, smaller isolated outcrops are found at both sides of the Rakovica Stream (west side of the Torlak hill). Likewise, less isolated parties of limestone have been discovered in the valley of the Mokri Lug Stream. Outcrops of limestone are found in the village of Lestane in eastern part of the city area. The development of Tortonian and Sarmatian limestones on the left and right banks of the Sava immediately before its confluence with the Danube is shown in the profile B-B (Fig. 4).

\section{MODEL OF KARST AQUIFER DISTRIBUTION IN BELGRADE AREA}

A model of limestone distribution in the urban area of Belgrade was developed based on surface development of limestone and data obtained by test drilling.

\section{BASIC CHARACTERISTICS OF KARST AQUIFER Conditions of aquifer recharge and discharge}

The dominant way of karst aquifer recharge is by rainfall infiltration. Factors that generally affect the recharge of aquifers in urban areas are:

- covering of the field by asphalt and concrete surfaces

asphalt and concrete surfaces reduce the possibility of rainfall infiltration while surface runoff is increased

- losses in water system network

losses in water system network participate in recharge of aquifers (the pipeline route passes through central parts of the city, from the Makis area on the Sava to the Tasmajdan area and is mostly laid in limestone). Losses in the network of $20 \%$ are equivalent to $300 \mathrm{~mm}$ of a rain annual height (Marsalek et al. 2007)

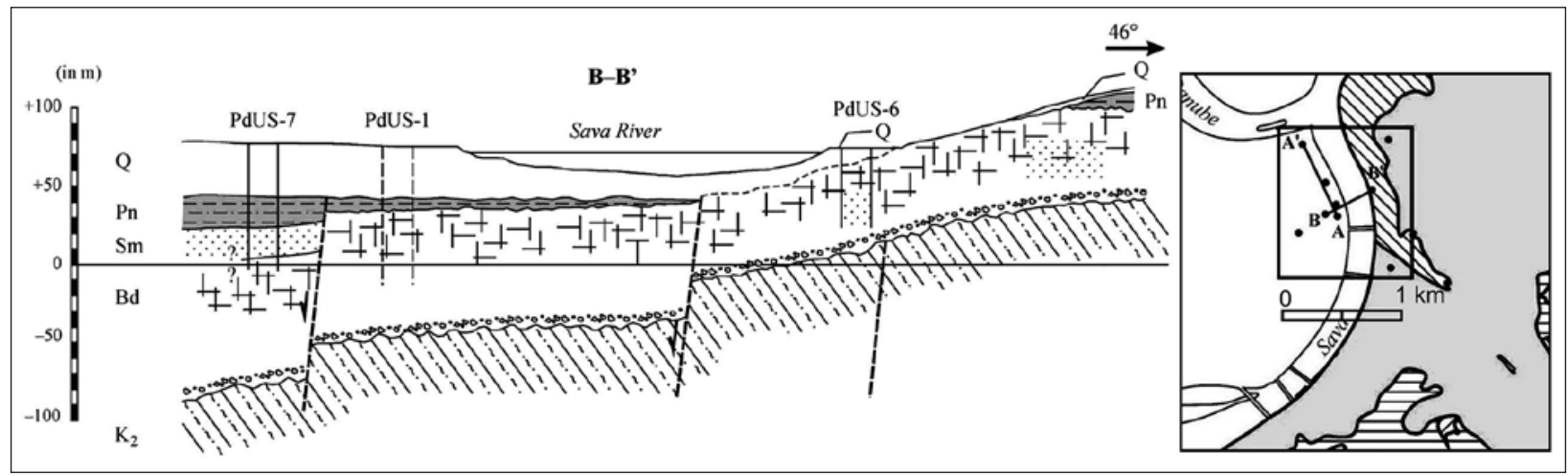

Fig. 4: Geological cross section of field near confluence of Sava and Danube (Rundic et al. 2011).

Legend: $K_{2}$ - Upper Cretaceous; Bd - Badenian limestone and sand; Sm - Sarmatian sand, marl and limestone; Pn - Pannonian marl and silty marl; $Q$ - Loess and other soft deposits 


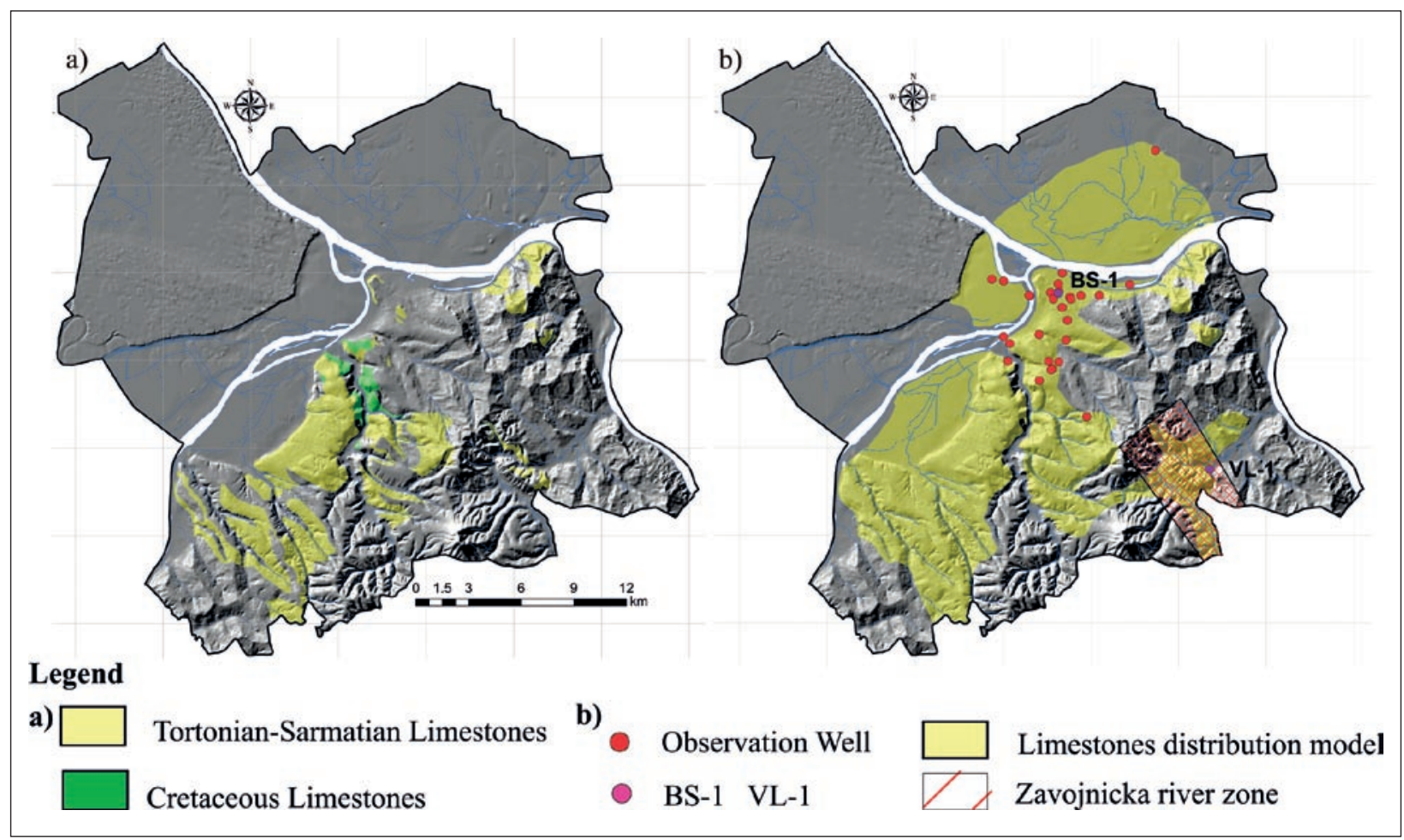

Fig. 5: a) Surface development of limestone. b) Conceptual model of assumed distribution of karst aquifer in Belgrade area (Vranjes 2012).

\section{- annual precipitation amount}

in urban areas there is $5-10 \%$ more precipititation on yearly basis than in rural areas, and in the course of a single shower there is $30 \%$ more precipitation in the city than in its rural areas. (Marsalek et al. 2007)

Karst waters are characterized by a stable temperature and chemical regime. The reason for this is depth to the groundwater level, which is over $15 \mathrm{~m}$ (deep aquifer water levels, which can reach depths up to $60 \mathrm{~m}$, are typical of Urgon age limestone) and slower water exchange.

The dominant form of karst aquifer discharge is by production wells. Groundwater temperatures and well yield within the karst aquifer are shown in Tab. 2 .

\section{GEOTHERMAL POTENTIAL OF KARST WATER IN BELGRADE AREA}

Up to now the use of karst water resources has been quite limited. The sources of water supply for the city of Belgrade were formed in alluvial deposits of the Sava, and the only purpose of the karst water was for the production of beer and soft drinks. Nowadays, the industrial production of beer and soft drinks is significantly reduced, half of the plant is closed, and the organized exploitation of the karst water almost does not exist.

With the development of heat pump technology new possibilities for the use of groundwater resources are opened. Heat pumps are devices that provide heat exchange, namely they subtract heat from one medium to add it to another one and vice versa. The working principle of a heat pump is based on the fol- lowing: the fluid from which heat is substracted is led to the evaporating side of the device, while the fluid to which the heat is delivered is led to the condenser of the device.

Energy potential of groundwater resources and its applicability in heat pump systems are defined by three factors: groundwater yield, groundwater temperature and chemism of groundwater. Thermal power source of groundwater is directly dependent on the amounts, the specific heat of water and temperature reductions that can be achieved in a heat pump, thus the temperature of resources does not exceed the freezing point.

Dependence is expressed by the following equation

$$
\mathrm{E}=\mathrm{C}_{\mathrm{p}} \times \mathrm{Q} \times \Delta \mathrm{T}
$$




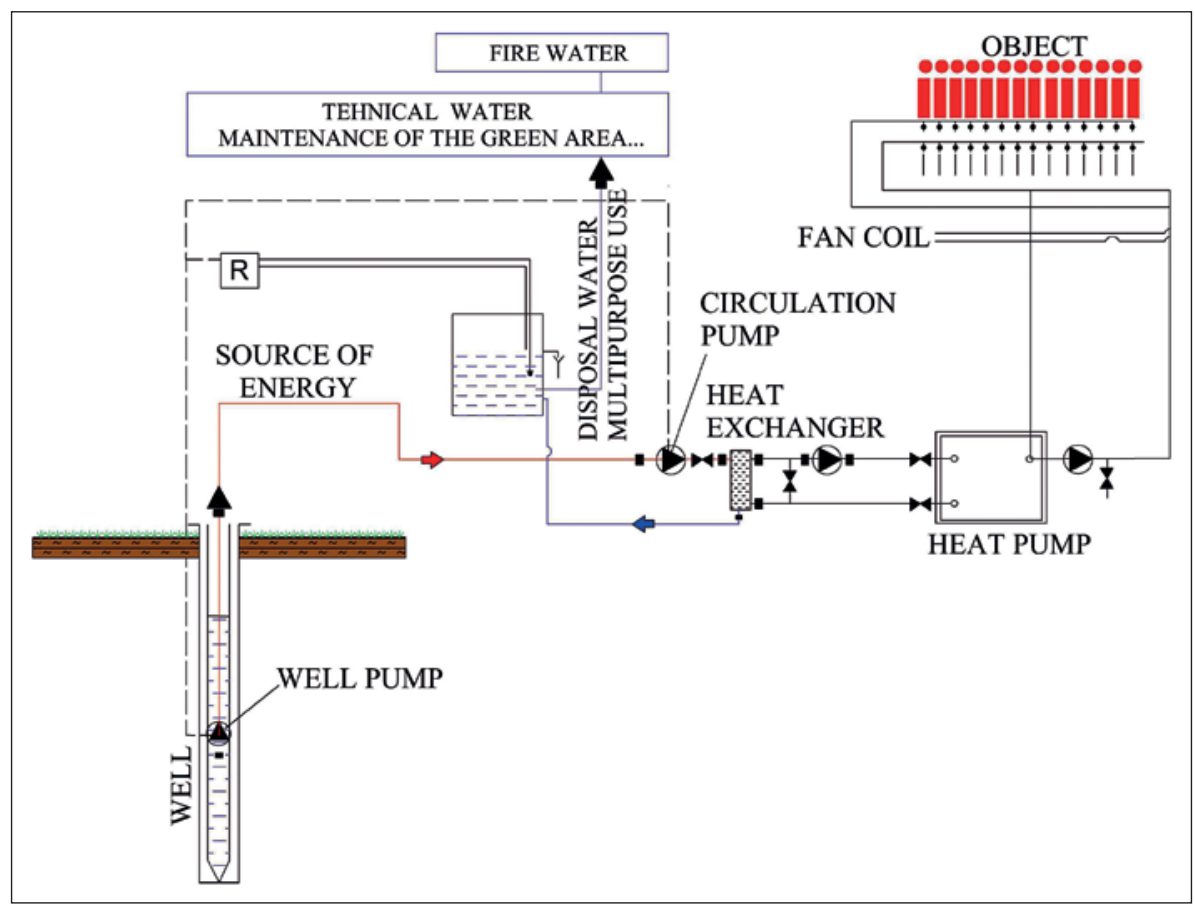

Fig. 6: Schematic view of multi-purpose utilisation of groundwater.
$\mathrm{E}$ - available nominal power $(\mathrm{kW})$

$\mathrm{C}_{\mathrm{p}}$ - specific heat of water (constant, $4.2 \mathrm{KJ} / \mathrm{kg} /{ }^{\circ} \mathrm{C}$ )

$\mathrm{Q}$ - yield of wells $(\mathrm{kg} / \mathrm{s}$, the same as $\mathrm{l} / \mathrm{s})$

$\Delta \mathrm{T}$ - temperature reduction which can be achieved in a heat pump (up to $5^{\circ} \mathrm{C}$ )

The calculation of available thermal power of karst water in the urban city area was made based on the results of hydrogeological research. The mean temperature of karst water $\left(17^{\circ} \mathrm{C}\right)$ obtained by years of observation of a network of wells and piezometers (Tab. 2) was used in calculation. Volumes of groundwater included in the calculation of thermal power were defined on the basis of the conceptual model of assumed karst distribution, karst aquifer geometry, effective porosity-estimated value of effective porosity of limestone is at $1 \%$ minimum. (Kresic 1997)

According to equation (1) thermal power of karst water in the city area is $47 \mathrm{MW}$, which is about $2 \%$ of the total installed capacity of district heating in the city area, that is $15 \%$ of the installed capacity of a heating plant which supplies the central city core parts.

During the exploitation of groundwater for the needs of heating/cooling, it is significant to act in accordance with the principles of optimization and maximum energy efficiency. The increase in the efficiency of the system is achieved by multi-purpose utilisation of groundwater. The scheme of multi-purpose utilisation of groundwater is shown in Fig. 6. Chemism of groundwater affects the sustainability of the designed heating/ cooling system significantly, beginning with the exploitation of resources, its application, to the disposition of resources. In developing of a well, the adverse impact of chemistry of groundwater is seen through the occurrences of corrosion or encrustations, which results in the reduction of exploitation, that is absorption capability of the well. The following components: the $\mathrm{pH}$ value, the content of iron and manganese, the content of calcium ions, then carbonate, bicarbonate, chloride, gases, water hardness, and mineralization affect the selection of materials, thermo-technical equipment, heat exchangers and heat pumps.

In Belgrade, hydrogeothermal energy is mostly used for heating/cooling of residential buildings. In recent years, the policy of geothermal energy use in public buildings such as educational institutions (schools) and institutions of social care (kindergartens) has been successfully implemented. The scheme of thermotechnical facilities installed in a building where mentally disordered people reside is presented in Fig. 7.

The building is located in the central part of the city. Its surface is $2500 \mathrm{~m}^{2}$. Three reversible heat pumps waterwater, with the heating capacities of $\mathrm{Q}_{\mathrm{gr}}=40.3 / 60.5 \mathrm{~kW}$, electric power of $\mathrm{P}_{\text {el.h. }} / \mathrm{P}_{\text {el.gr. }}=8 / 13.4 \mathrm{~kW}$, the coefficient of efficiency $\mathrm{COP}=4.52$, and the ratio of energy efficiency $\mathrm{EER}=5.04$ have been installed in the building. Each heat pump has its heat exchanger, rated at $47 \mathrm{~kW}$ capacity. The heat exchanger type is: LPM-LSL1-40, the primary fluid in the heat exchanger is $16^{\circ} \mathrm{C} / 8^{\circ} \mathrm{C}$, and the secondary $4^{\circ} \mathrm{C} / 8^{\circ} \mathrm{C}$.

For the purpose of providing resources a production well was developed. The well was developed in Sarmatian limestone. The depth of the well is $100 \mathrm{~m}$, the 


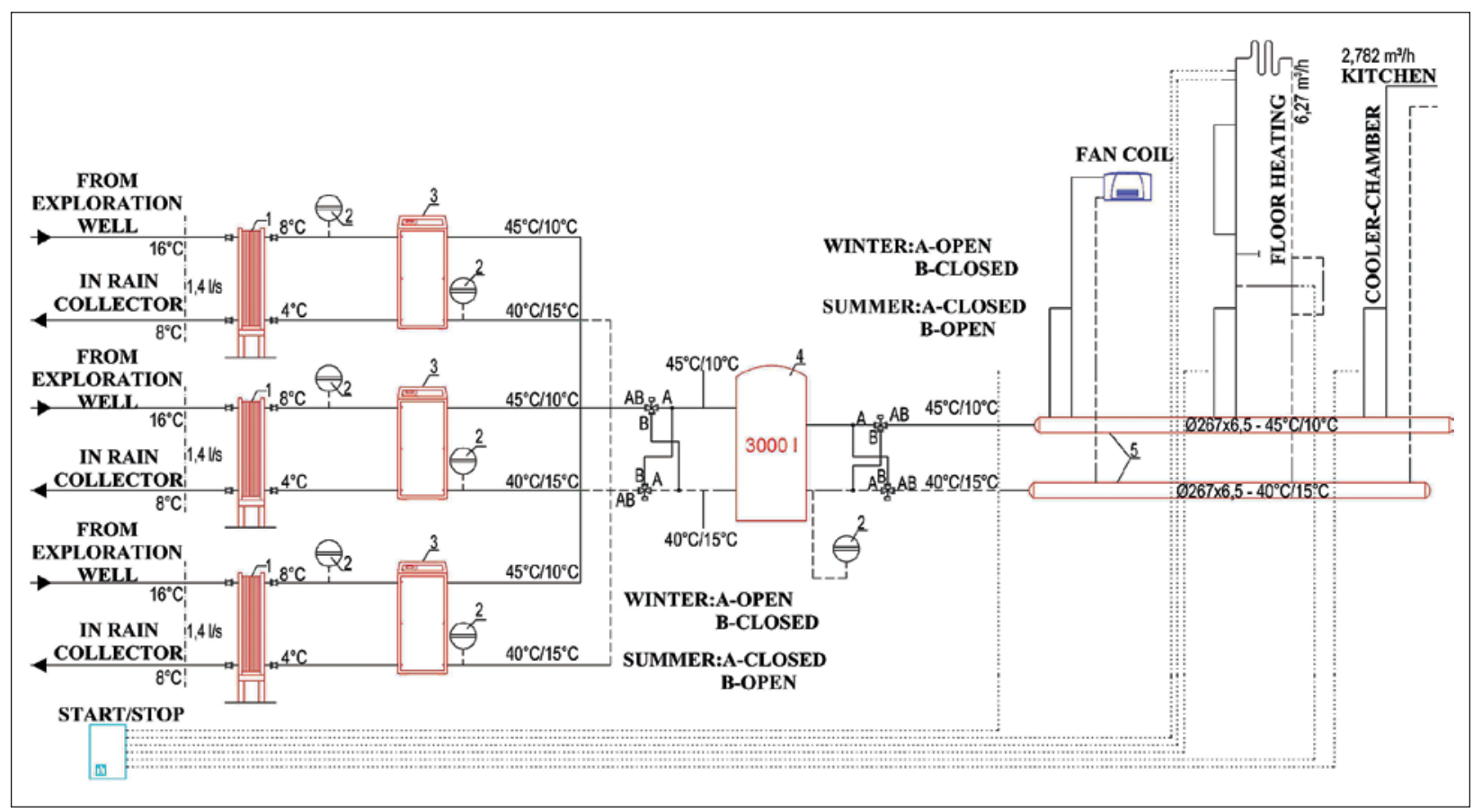

Fig. 7: Scheme of thermotechnical installations of building in central part of city (modified from Slavica 2012). 1-Heat Exchanger; 2-Closed membran expansion tank; 3-Heat pump; 4-Buffer hot water; 5-Splitter/Collector.

yield $6 \mathrm{l} / \mathrm{s}$, and the groundwater temperature is $16{ }^{\circ} \mathrm{C}$. The well is equipped with a well pump with the capacity of $5.5 \mathrm{l} / \mathrm{s}$ for the lift height of $\mathrm{H}=60 \mathrm{~m}$. The power of the pump motor is $7.5 \mathrm{~kW}$.
Groundwater with the temperature of $16^{\circ} \mathrm{C}$ flows from a well to a heat exchanger, where the heat is exchanged. The temperature of well water drops to $8{ }^{\circ} \mathrm{C}$ and then the water runs to the rain collector.

\section{PROBLEMS OF SUSTAINABLE UTILISATION OF GEOTHERMAL RESOURCES IN URBAN AREAS}

The exploitation of geothermal resources in the concept of air conditioning of facilities should be conducted in a manner that does not threaten groundwater reserves, in terms of quantity and quality. Likewise, the disposition or disposal of "energy utilized" groundwater should be conducted in a manner that does not threaten surface and ground waters in terms of quantity and quality. Generally, there are three ways of dispositioning the groundwater: letting it flow into open recipients (rivers, canals), letting it flow into closed recipients (rain collectors, sewage system), bringing it back to the aquifer (infiltration, injection well). In urban areas two most common ways of the groundwater disposal are letting it flow into rain collectors or injection of the groundwater into the aquifer via injection wells.

The increase in the share of geothermal energy in the total energy balance of the city carries the potential risk of endangering resources and causing offensive state of karst water. A negative effect on the groundwater may be due to:

Exploitation of resources beyond legally prescribed conditions. The failure to comply with legal procedures in the research stage and then in the stage of groundwater exploitation implies the lack of compulsory design and accompanying technical documentation. Project solutions and conditions of groundwater exploitation developed by experts are provided by project documentation, whereby conditions for sustainable use and monitoring of groundwater are achieved.

Uncontrolled exploitation of resources, most frequently by unqualified persons. Practice has shown that with an increasing number of facilities using geothermal energy in the Belgrade area, the number of unqualified persons responsible for protecting resources has also increased, thus problems both in the phase of the drilling of wells in the karst environment, as well as in the exploitation 

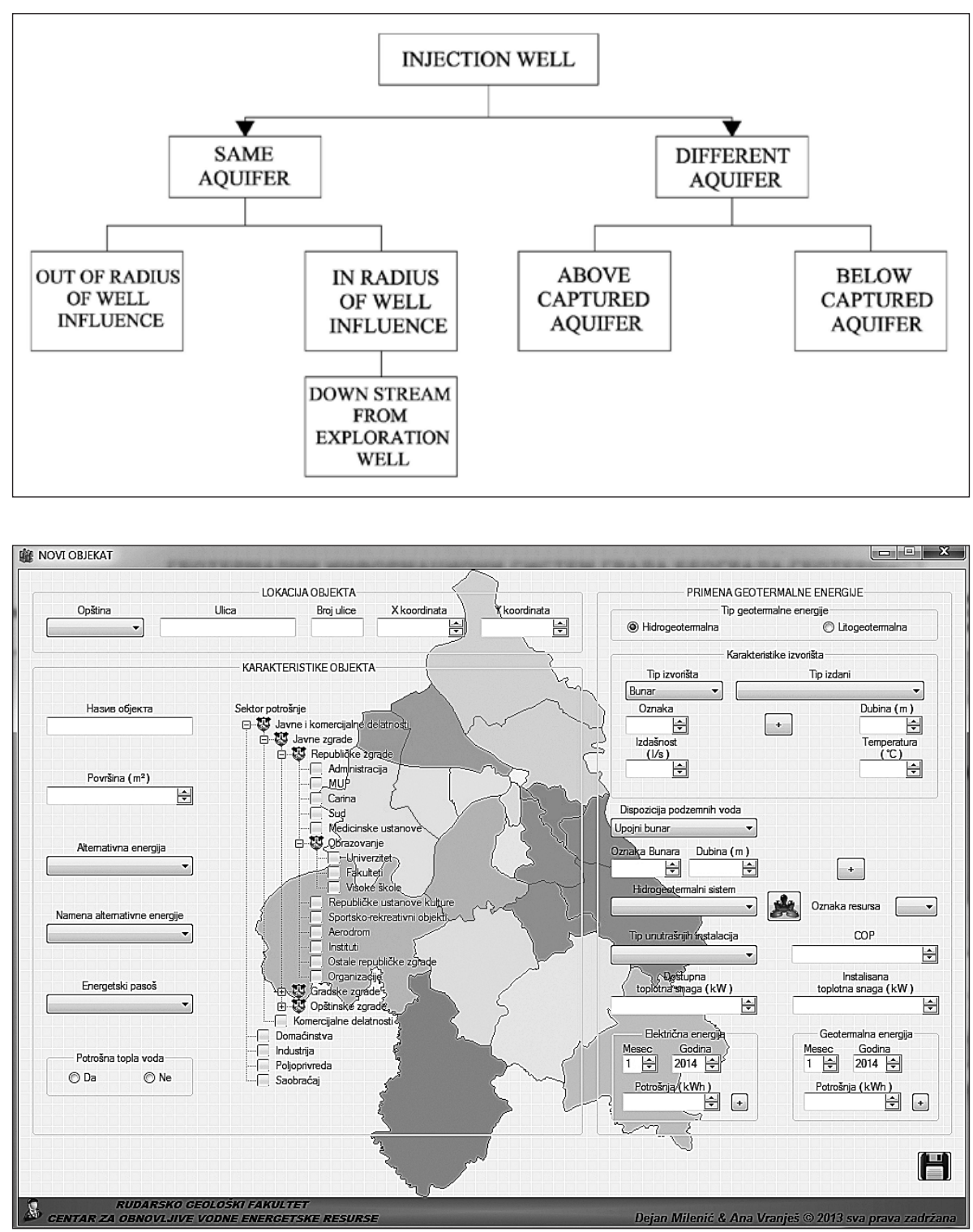

Fig. 8: Flowchart of different solutions for injection well.

Fig. 9: Appearance of the main window of geothermal information database Geothermist. phase arise. Unsuccessful drilling of a well poses a risk to groundwater contamination. During exploitation, due to neglecting of legally prescribed research procedures on a well (pumping tests and conducting of chemical analysis, as well as monitoring changes in temperature and groundwater levels) overexploration of wells, changes in water chemistry, and therefore the failure of the entire system, occur.

Uncontrolled disposal of groundwater after running through heat pump system. Disposal of "energy utilized" karst water in the urban environment is a complex engineering requirement, with regard to that natural temperature conditions are altered as a result of a "poorly" designed system of restoring resources to the aquifer.
Restricted availability of free surfaces (land occupancy by constructed facilities) is a limitation occurring in urban areas in designing of injection wells. In Fig. 8, there is shown the flowchart of variant solutions for groundwater disposal to the aquifer via the injection well.

With the aim of preventing the aforementioned negative consequences, the Geothermal Information Database (Milenic \& Vranjes 2013), called Geothermist was built up for the area of Belgrade. The basic aim of establishing of an information database is the systematization and categorization of geothermal research data, in order to activate mechanisms for sustainable management of geothermal resource utilisation in the city. In Fig. 9, there is shown the layout of the main window for data entry. 


\section{CONCLUSION}

The assessment of the geothermal potentiality of the terrain from the point of view of energy evaluation and possibilities of the exploitation of karst water resources was carried out in the area of Belgrade. In the research process, an analysis of geological setting of the field was carried out, and hydrogeological characteristics of the field, as well as geothermal indicators in the city area perceived. Based on the results of the analysis, a conceptual model of the assumed distribution of the karst aquifer was developed. The interpretation of data related to the yield of wells, the temperature and quality of the groundwater was made. The data were classified and used to make maps of isotherms for the city area. After completing all necessary bases, the calculations of thermal power of karst water followed. From the relation between the mean value of groundwater temperature, and the amount and the specific heat of the water it has been calculated that the thermal power from karst groundwater in the urban city area is $47 \mathrm{MW}$.

Recently there has been an increase in the number of buildings in the city area that use karst water as an energy source for heating/cooling. While designing such systems of climatisation, it is important to follow the principle of optimization and the principle of maximum energy efficiency, and it can be reached by multi-purpose use of the groundwater. In low-temperature climatisation systems, karst groundwater, after it goes through the heat exchanger, and depending on the buliding's needs, may be used for the maintenance of the green area surrounding the building or for the sake of fire protection. And if the quality is good enough, it may be used for the building's water supply and welness and spa purposes.

The problem of sustainable utilization of geothermal resources in urban areas is related to the exploitation conditions and the disposition of the "energy" utilized groundwater. Restrictions in the use and disposition of groundwater in urban areas are related to the degree up to which the field is constructed. Two most common ways of the groundwater disposal in urban areas are letting it flow into a closed recipient (rain collector) or constructing injection wells. The calculation of the optimum distance between the two wells is the greatest challenge in forming the doublets. An inadequately designed injection well, regarding its position in relation to the exploitation well, can lead to the change of primary conditions of the system functioning, in form of hydraulic feedback and thermal feedback. The sustainability of such systems is only possible with proper management mechanisms. Uncontrolled exploitation of karst resources in terms of the overexploitation of resources, or the system development without the design documentation, endangers the resource from the aspects of both amount and quality.

\section{REFERENCES}

Cermak, V. \& L. Rybach (eds.), 1979: Terrestrial Heat Flow in Europe, Springer Verlag, pp. 328, Berlin.

Cukovic Ignjatovic, N., 2009: Problems of Front Cover Treatment in Contemporay Approach to Building Alteration, Master's thesis, University of Belgrade, Faculty of Architecture.

Dokmanovic, P., 1997: Hydrogeological Characteristics of Tertiary Basins in Serbia south of Sava and Danube, $\mathrm{PhD}$ thesis, University of Belgrade, Faculty of Mining and Geology.

Knezevic, S. \& M. Sumar, 1994: Contribution to Geology Knowledge of City of Belgrade.-Annales géologiques de la péninsule Balkanique, 58, 2, 73-81.

Kresic, N., 1997: Hydrogeology and groundwater modeling, CRC, pp. 363, Florida.

Marsalek, J., Jienez-Cisneros, B., Karamouz, M., Malmquist, P.A., Goldenfum, J. \& B. Chocat, 2007: Urban Water Cycle Processes and Interactions, Urban Water Series-UNESCO-IHP, pp. 131, Paris.
Milenic, D. \& A. Vranjes, 2013: Geothermist, Geothermal information database of Belgrade city area, Licensed software, University of Belgrade, Faculty of Mining and Geology, Belgrade

Milivojevic, M., 1982: Paleohydrogeothermal Occurrences of Avala, University of Belgrade, Faculty of Minig and Geology, pp. 203, Belgrade.

Milivojevic, M., 1989: Evaluation of Geothermal Resources of Territory of Serbia without Autonomous Provinces, $\mathrm{PhD}$ thesis, Univesity of Belgrade, Faculty of Minig and Geology, Belgrade.

Rundic, Lj., Ganic, M., Knezevic, S. \& A. Soliman, 2011: Upper Miocene Pannonian sediments from Belgrade (Serbia): new evidence and paleoenvironmental considerations.- Geologica Carpathica, 62, 3, 267-278. 
Santamouris, M., 2007: Energy in Buildings and Citizenship, Proceedings of 38 International congress on heating, cooling and air conditioning, $5^{\text {th }}-7^{\text {th }}$ December 2007, Belgrade, 13-26, Belgrade.

Slavica, V., 2012: Main Design of thermotechnical instalation, Institution for the casual and temporary residence "Predah" with the necessary facilities, Shakespeare street, Belgrade, project reports, Institute of Transportation, CIP.
Unkasevic, M., 1994: Climate of Belgrade, Scientific book, Belgrade.

Vranjes, A., 2012: Hydrogeothermal resources of the Belgrade city area, $\mathrm{PhD}$ thesis, University of Belgrade, Faculty of Mining and Geology, pp. 617. 